\title{
Dendritic Cells Express Hematopoietic Prostaglandin D Synthase and Function as a Source of Prostaglandin D2 in the Skin
}

\author{
Chieko Shimura, ${ }^{*}$ Takahiro Satoh, ${ }^{*}$ Ken Igawa, ${ }^{*}$ \\ Kosuke Aritake, ${ }^{\dagger}$ Yoshihiro Urade, ${ }^{\dagger}$ \\ Masataka Nakamura, ${ }^{\ddagger}$ and Hiroo Yokozeki ${ }^{\star}$ \\ From the Department of Dermatology,* Graduate School, Tokyo \\ Medical and Dental University, Tokyo, the Department of \\ Molecular and Behavioral Biology, ' Osaka Bio science Institute, \\ Osaka, and the Human Gene Sciences Center, ${ }^{\neq}$Tokyo Medical \\ and Dental University, Tokyo, Japan
}

Prostaglandin D2 (PGD2), an arachidonic acid metabolite, has been implicated in allergic responses. A major source of PGD2 in the skin is mast cells that express hematopoietic PGD synthase (H-PGDS). In this study, we show the expression of H-PGDS in human dendritic cells (DCs) and the regulatory mechanisms by which DCs produce PGD2. We detected H-PGDS in epidermal Langerhans cells, dermal DCs, plasmacytoid DCs, and myeloid DCs. Monocyte-derived DCs rapidly secreted PGD2 when stimulated with the calcium ionophore A23187. More importantly, pretreatment of monocyte-derived DCs with PMA (phorbol 12-myrisate 13-acetate) synergistically enhanced the rapid PGD2 secretion induced by A23187, whereas PMA alone did not induce PGD2 secretion. Lipopolysaccharide (LPS) reduced H-PGDS expression, but interferon- $\gamma$ followed by LPS induced significant PGD2 production in a delayed time course at 6 hours. This effect was associated with inhibition of LPS-induced H-PGDS reduction. Interestingly, an irritant compound, SDS, also induced a rapid PGD2 release. PGD2 synergistically enhanced CCL22/macrophage-derived chemokine synthesis in interferon$\gamma$-treated human keratinocytes. In addition, bone marrow-derived DCs from wild-type mice stimulated lymph node cells to produce higher amounts of interleukin-17 than did DCs from mice lacking the H-PGDS gene. Thus, DCs could be an important source of skin PGD2 and may mediate or regulate skin inflammation by releasing PGD2 in response to various stimuli, contributing to the innate and/or acquired immune responses. (Am J Patbol 2010, 176:227-237; DOI: 10.2353/ajpath.2010.090111)

Prostaglandin D2 (PGD2) is one of the arachidonic acid metabolites and exerts a range of biological activities, including vasodilatation, bronchoconstriction, and inhibition of platelet aggregation. ${ }^{1-4}$ PGD2 is also implicated in allergic diseases. PGD2 production is observed in bronchoalveolar lavage fluid from asthmatic patients. ${ }^{5}$ Mice that overproduce PGD2 exhibit an enhanced allergic lung response, eosinophilia, and increased Th2-type cytokine production. ${ }^{6}$ We have demonstrated that PGD2 plays an essential role in IgE-mediated skin responses in mice. ${ }^{7}$ A possible anti-pruritic potential of PGD2 in the scratching behavior of mice was recently proposed. ${ }^{8,9}$

PGD2 exerts its effect through D prostanoid (DP) and CRTH2 (chemoattractant receptor-homologous molecule expressed on Th2 cells) receptors. DP and CRTH2 are members of the $G$ protein-coupled, seven transmembrane receptor family. DP is coupled with Gs protein, whereas Gi protein is associated with CRTH2. ${ }^{10}$ DP-mediated signals inhibit dendritic cell (DC) migration. ${ }^{11-13}$ Effects of PGD2 on DC maturation and interleukin-12 production are also mediated by the DP receptor. ${ }^{14}$ On the other hand, CRTH2 signals induce calcium mobilization and chemotaxis in eosinophils and basophils. ${ }^{10}$ In addition, CRTH2 signals enhance interleukin-4, -5 , and -13 production from Th2 cells. ${ }^{15}$

PGD2 synthesis is mediated by the isomerization of prostaglandin $\mathrm{H} 2$ (PGH2) into PGD2 through the enzymatic activity of PGD synthase (PGDS). ${ }^{16}$ Two types of PGDS have been identified: lipocalin-type PGDS and hematopoietic PGDS (H-PGDS). ${ }^{16,17}$ Lipocalin-type PGDS is present in meningeal cells, epithelial cells of the choroids plexus, and oligodendrocytes in the brain and is involved in the sleep-wake cycle. ${ }^{18} \mathrm{H}$-PGDS was origi-

\footnotetext{
Accepted for publication September 22, 2009

Address reprint requests to Takahiro Satoh, M.D., Ph.D., Department of Dermatology, Graduate School, Tokyo Medical and Dental University, 1-5-45 Yushima, Bunkyo-ku, 113-8519, Japan. E-mail: tasa-1688.derm@ tmd.ac.jp.
} 
nally isolated from rat spleen as a cytosolic glutathione (GSH)-requiring enzyme. ${ }^{19,20}$ Mast cells express H-PGDS and rapidly secrete PGD2 in response to antigen stimulation. ${ }^{21,22}$ Thus, mast cells are a major source of PGD2 in the skin and contribute to inflammation, ${ }^{23,24}$ although a small population of Th2-type cells contains H-PGDS. ${ }^{25}$

$\mathrm{H}-\mathrm{PGDS}$ is also detected in antigen-presenting cells, such as histiocytes and/or DCs in rat spleen, thymus, and skin. ${ }^{26,27}$ We have revealed that epidermal Langerhans cells in mouse skin express H-PGDS. ${ }^{7}$ Thus, it can be postulated that DCs could be a source of PGD2 in skin tissues and may affect various immune cells and effector cells, including DCs themselves, through DP and/or CRTH2 receptors. However, H-PGDS in human DCs and their capability for PGD2 secretion have not been fully characterized. In the present study, we analyzed H-PGDS expression in human DCs and identified regulatory mechanisms of PGD2 production with a variety of stimuli. Moreover, the biological significance of DC-derived PGD2 in terms of chemokine synthesis from keratinocytes and cytokine production from lymphocytes were also assessed.

\section{Materials and Methods}

\section{Antibodies}

Fluorescein isothiocyanate (FITC)-conjugated anti-human CD303 monoclonal antibody (mAb) (BDCA-2-FITC) (AC144), CD1C (BDCA-1-FITC) (AD5-8E7), and CD19-PE (HIB19) were purchased from Miltenyi Biotechnology (Auburn, CA). CD1a-FITC (HI149), CD123-PE-Cy5 (7G3), CD45-PE (HI100), CD86-PE (IT 2.2), and TLR-4-PE (HTA125) were purchased from eBioscience, Inc. (San Diego, CA). CD207 (Langerin)-R-PE (DCGM4) was purchased from Immunotech SAS (Marseille, France), and HLA-DR-FITC (L243) was purchased from BD Biosciences Pharmingen (Franklin Lakes, NJ). Control mouse IgG1 was obtained from Dako Cytomation (Glostrup, Denmark).

\section{Immunohistochemical Staining}

This study was approved by the ethics committee of the Tokyo Medical and Dental University. We prepared 5 - $\mu \mathrm{m}$-thick frozen tissue sections of skin biopsy specimens from normal skin or from patients with atopic dermatitis (AD) who had provided informed consent. The tissue sections were fixed for 10 minutes in ice-cold methanol, air dried, and incubated in PBS containing $10 \%$ normal goat serum, $0.01 \%$ Triton- $\mathrm{X}$, and $0.1 \% \mathrm{NaN}_{3}$ to block nonspecific binding. They were then incubated with rabbit polyclonal anti-human H-PGDS Ab (established at the Osaka Bioscience Institute, Osaka, Japan) or with control rabbit immunoglobulins (Dako Cytomation), followed by incubation with TRITC-conjugated (Dako Cytomation) or FITC-conjugated (Santa Cruz Biotechnology, Santa Cruz, CA) goat anti-rabbit IgG. The sections were then double- or triple-stained with antibodies against several cell surface markers. Immunostained samples were examined under a confocal laser scan- ning microscope (LSM510, Carl Zeiss, Oberkochen, Germany).

\section{Flow Cytometry}

Buffy coat cells, peripheral blood mononuclear cells, or isolated DCs were washed and resuspended in PBS containing $5 \%$ fetal calf serum and $0.1 \% \mathrm{NaN}_{3}$. They were stained with mAbs against surface markers of dendritic cells. Using an IntraStain kit (Dako Cytomation), intracellular H-PGDS was detected by staining with polyclonal rabbit anti-human H-PGDS Ab followed by the

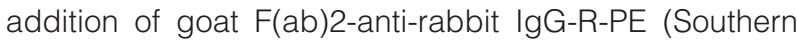
Biotechnology Associates, Inc., Birmingham, AL) or with R-PE-conjugated anti-human H-PGDS mAb (EBC45). ${ }^{25}$ The rabbit immunoglobulin fraction (Dako Cytomation) was used as a negative control Ab.

\section{Isolation of Plasmacytoid DCs and Myelod DCs}

Buffy coats from healthy donors were obtained from the Institute of Japanese Red Cross Society. Peripheral blood mononuclear cells from healthy volunteers were prepared from the buffy coats or from whole blood anticoagulated with EDTA obtained by Ficoll-Paque (GE Health Care Bio-Sciences AB, Uppsala, Sweden) density gradient centrifugation. Dead cells and CD14 ${ }^{+}$cells were initially depleted with a Dead Cell Isolation kit (Miltenyi Biotech) followed by magnetic negative selection with CD14-microbeads (Miltenyi Biotech). Plasmacytoid dendritic cells ( $p D C s$ ) were isolated by magnetic positive selection with CD304 (BDCA-4)-microbeads (Miltenyi Biotech). Myeloid dendritic cells (mDCs) were isolated by magnetic positive selection with CD1c (BDCA-1)-microbeads following the depletion of $\mathrm{CD} 19^{+}$cells.

\section{Generation of Monocyte-Derived DCs}

$\mathrm{CD}_{14}{ }^{+}$cells from healthy volunteers were isolated by magnetic positive selection with CD14-microbeads (TUK4, Miltenyi Biotech). They were then cultured in the presence of recombinant human granulocyte macrophage-colony stimulating factor (50 ng/ml) (PeproTech, Rocky Hill, NJ) and interleukin-4 (20 ng/ml) (PeproTech) for 7 days. Before the experiments, monocyte-derived DCs (MoDCs) were seeded in a 24-well micro-titer plate at $1 \times 10^{6} \mathrm{cell} / \mathrm{ml}$ and incubated for 1 hour. MoDCs were incubated with various stimuli in the presence of interleukin-4 and GM-CSF to sustain their viability, except for in some experiments. The purity of the DCs was greater than 95\%, as determined by CD1a and CD206 staining (BD Biosciences Pharmingen).

\section{Western Blotting for H-PGDS}

Cell lysates were centrifuged and subjected to SDSpolyacrylamide gel electrophoresis on $15 \%$ polyacrylamide gels under reducing conditions. Proteins were transferred onto Hybond-P polyvinylidene difluoride transfer membrane (Amersham Biosciences, Pittsburgh, 
PA) and stained with anti-H-PGDS mAb (1E6) that was established at the Osaka Bioscience Institute. Reactive products were visualized by the ECL system (Amersham Biosciences) with a horseradish peroxidase-conjugated secondary $\mathrm{Ab}$.

\section{Real-Time PCR}

Total cellular RNA was isolated by using Isogen (Nippon Gene Co., Ltd., Tokyo, Japan). Twenty microliters of reverse transcription mix consisted of $8 \mu$ l of $5 \times$ buffer $(250$ $\mathrm{mmol} / \mathrm{L}$ Tris- $\mathrm{HCl}, \mathrm{pH} 8.3,375 \mathrm{mmol} / \mathrm{L} \mathrm{KCl}, 50 \mathrm{mmol} / \mathrm{L}$ DTT, $15 \mathrm{mmol} / \mathrm{L} \mathrm{MgCl}_{2}$ ), $4 \mu \mathrm{l}$ of hexanucleotide mixture (62.5 $\mathrm{A}_{260} \mathrm{U} / \mathrm{ml}$; Roche Diagnostics $\mathrm{GmbH}$, Mannheim, Germany), $2 \mu \mathrm{l}$ of dNTPs ( $2.5 \mathrm{mmol} / \mathrm{L}$ each), $4 \mu \mathrm{l}$ of 20 $\mathrm{u} / \mu \mathrm{l}$ of human placenta ribonuclease inhibitor (Takara Biomedicals, Shiga, Japan), and $2 \mu$ of $200 \mathrm{u} / \mu$ l reverse transcriptase (Moloney murine leukemia virus; Takara Biomedicals). A total of $20 \mu \mathrm{l}$ of the reverse transcription mix and $20 \mu \mathrm{l}$ of $40 \mathrm{ng} / \mu \mathrm{l}$ total RNA were combined in a tube and vortex-mixed. Reactions were performed at $37^{\circ} \mathrm{C}$ for 60 minutes. Reverse transcriptase was inactivated at $70^{\circ} \mathrm{C}$ for 10 minutes, and then the samples were stored at $-80^{\circ} \mathrm{C}$.

Quantitative RT-PCR was performed by monitoring in real time the increase in fluorescence of the SYBR Green dye (Brilliant SYBR Green QPCR Master Mix, Stratagene, La Jolla, CA) with the Mx3000P Real-Time PCR system (Stratagene). The PCR primers were as follows: 5'-CGCGAGAAGATGACCCAGATC-3' and 5'ATCACGATGCCAGTGGTACGG-3' for human $\beta$-actin; 5'-GCTGACTGGCCTGAAATCAAATC-3' and 5'-CCAGAGTGTCCACAATAGCATCAAC-3' for human H-PGDS; 5'-(CGGCCACATTTATGGAGACAATC)-3' and 5'-(TTCTACCGAGGGCGGGTACA)-3' for human cyclooxygenase (Cox)-1; 5'-(TGACCAGAGCAGGCAGATGAA)-3' and 5'(CCACAGCATCGATGTCACCATAG)-3' for human Cox-2; 5' -(ATGATAGCTCGGACAGTGATGATGA)-3' and 5'-(CATACGATGAATCCAACTTGCTTGA)-3' for human cytosolic phospholipase A2 (cPLA2); 5'-AGGATGATGCCAGGATGATGTC-3' and 5'-TCAGGTCCAGGTTCTTGGTTGAG-3' for human toll-like receptor 4 (TLR4); and 5'GCGTGGTGAAACACTTTTACTGGA-3' and 5'-TCATCTTCACCCAGGGCACTC-3' for human CCL22/macrophage-derived chemokine.

\section{Assay for PGD2 Production}

MoDCs $\left(1 \times 10^{6}\right.$ cells $\left./ \mathrm{ml}\right)$ were incubated with several stimulants. Supernatants were collected and PGs were eluted by ethyl acetate containing $1 \%$ methanol with C-18 SPE cartridge (Cayman Chemicals, Ann Arbor, $\mathrm{MI}$ ). Concentrations of PGD2 were measured by using a ProstaglandinD2-Mox Enzyme Immunoassay kit (Cayman Chemicals).

\section{Thin-Layer Chromatography}

MoDCs were prelabeled with $\left[1-{ }^{14} \mathrm{C}\right]$ arachidonic acid $(3.7 \mathrm{kBq} /$ well) for 6 hours in culture medium containing
interleukin-4/GM-CSF. After the removal of the medium, cells were stimulated with A23187 (5 $\mu \mathrm{mol} / \mathrm{L})$ (Sigma Aldrich, Inc., St. Louis, MO). Culture supernatants were collected, replaced at various intervals, and stored at $-80^{\circ} \mathrm{C}$ until the measurement of PGs. The products were extracted by ethyl acetate, separated by thin-layer chromatography, and then detected by using an imaging plate system (Fuji Film, Tokyo, Japan).

\section{Preparation and Stimulation of Normal Human Keratinocytes}

Normal human skin was obtained from patients who underwent plastic surgery and gave informed consent. Keratinocytes were prepared by treating skin tissues with dispase (200 u/ml, Sankojunyaku Co. Ltd., Tokyo, Japan) overnight at $4^{\circ} \mathrm{C}$ followed by treatment with $0.05 \%$ trypsin-EDTA (Invitrogen Corp., Carlsbad, CA) for 10 minutes at $37^{\circ} \mathrm{C}$. Cells were cultured in Keratinocyte-SFM medium (Invitrogen Corp.) and used after 3 to 5 passages with approximately $70 \%$ confluency.

\section{Mice}

BALB/c mice were purchased from Sankyo Laboratory Service Co. (Tokyo, Japan). H-PGDS ${ }^{-1-}$ mice described previously ${ }^{28}$ were backcrossed to BALB/c mice for more than 10 generations. Mice were maintained under specific pathogen-free conditions in our animal facility. The use of animals was in full compliance with the guidelines of the Committee for Animal Experiments of Tokyo Medical and Dental University.

\section{Mouse Bone Marrow-Derived DCs}

Bone marrow cells $\left(2 \times 10^{6}\right.$ cells $)$ were cultured with 10 $\mathrm{ml}$ of RPMI-1640/10\% FCS containing $20 \mathrm{ng} / \mathrm{ml}$ of murine GM-CSF (PeproTech). After 3 days, another $10 \mathrm{ml}$ of medium containing GM-CSF was added to each dish. At day 7 , nonadherent cells were harvested followed by positive selection with CD11c-coated microbeads (Miltenyi Biotech) and used as bone marrow-derived DCs (BMDCs). The purity of $\mathrm{CD}_{11 \mathrm{c}^{+}}$cells was greater than 95\%. BMDCs were incubated with $2 \mathrm{mmol} / \mathrm{L}$ 2,4-dinitrobenzene sulfonic acid sodium salt (Alfa Aesar, Ward Hill, MA) in PBS for 15 minutes at $37^{\circ} \mathrm{C}$. Cells were washed three times with PBS and used as dinitrophenyl (DNP)modified bone marrow-derived DC (DNP-DC).

\section{Preparation and Stimulation of Immune Lymph Node Cells}

Mice were sensitized with 2,4-dinitrofluorobenzene (Nacalai Tesque, Inc., Kyoto, Japan) on the ventral skin. Five days later, abdominal lymph node ( $L N)$ cells were collected. Immune LN cells $\left(2 \times 10^{5}\right.$ cells $)$ were stimulated with DNP-DC $\left(2 \times 10^{4}\right.$ cells $)$ for 24 hours and supernatants were collected. Cytokines were determined with enzyme-linked immunosorbent assay kits according 
to the manufacturer's instructions. Enzyme-linked immunosorbent assay kits for mouse interleukin-4, interleukin17 , and interferon- $\gamma$ (IFN- $\gamma$ ) were purchased from R and D Systems, Inc (Minneapolis, MN).

\section{Statistical Analyses}

The Student's $t$ test was used to assess the statistical significance of differences between mean values.

\section{Results}

\section{Langerhans Cells Express H-PGDS}

Immunohistochemical staining of normal skin with a rabbit polyclonal anti-H-PGDS Ab revealed that a number of $\mathrm{CD} \mathrm{a}^{+}$epidermal Langerhans cells expressed H-PGDS (Figure 1A, upper panel). These data are consistent with prior studies of rat and mouse skin ${ }^{7,26}$ but different in that only a portion of human Langerhans cells express H-PGDS. We next examined the H-PGDS expression in inflamed skin (ie, AD). A portion of the epidermal Langerhans cells in $A D$ skin also expressed H-PGDS as in normal skin. The prevalence of $\mathrm{H}_{-} \mathrm{PGDS}^{+}$cells in total $\mathrm{CD} 1 \mathrm{a}^{+}$epidermal Langerhans cells in chronic skin lesions of patients with $\operatorname{AD}(n=4)$ $(69.3 \% \pm 16.0 \%)$ tended to be higher than that in normal skin $(n=4)(50.9 \% \pm 17.3 \%)$; however, the difference was not statistically significant (Figure 1B). There were also a small number of $\mathrm{CD} 207^{+} / \mathrm{H}-\mathrm{PGDS}^{+}$cells underneath the epidermis (Figure 1A, middle panel).

\section{H-PGDS Expression in Dendritic Cell Populations in the Dermis}

The results that epidermal Langerhans cells express $\mathrm{H}$-PGDS prompted us to determine whether H-PGDS is expressed in other types of DC populations in the

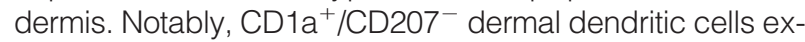
pressed H-PGDS (Figure 1A, lower panel). Moreover, $\mathrm{BDCA}-2^{+} / \mathrm{CD} 23^{+} \mathrm{pDCs}$ and $\mathrm{BDCA}-1^{+} \mathrm{mDC}$ were also positive for H-PGDS (Figure 2A).

\section{Peripheral Blood DCs Express H-PGDS}

We next examined the expression of H-PGDS in blood DCs. We initially examined H-PGDS expression in pDCs and $\mathrm{mDCs}$ by a flow cytometric analysis of wholeblood. Whole-blood flow cytometric analysis revealed that $\mathrm{BDCA}-2^{+} / \mathrm{CD}_{123^{+}} \mathrm{pDCs}$ and $\mathrm{BDCA}-1^{+} / \mathrm{CD} 19^{-}$ mDCs contained intracellular H-PGDS (Figure 2B). To confirm the presence of H-PGDS in these cell populations, we isolated pDCs and mDCs from peripheral blood, as described in Materials and Methods. The purity of the cell suspensions is shown in Figure 3A. Both freshly isolated pDCs and mDCs expressed intracellular H-PGDS, as detected by positive staining with mouse monoclonal anti-H-PGDS Ab (EBC45) (Figure 3B, left). ${ }^{25}$ We also confirmed the presence of H-PGDS transcripts in these freshly isolated DCs in vitro (Figure 3B, right).
A
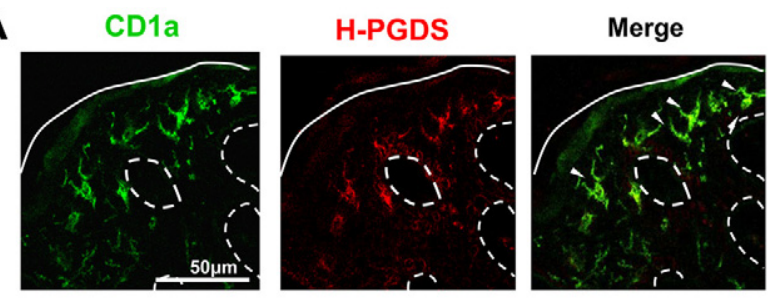

CD207

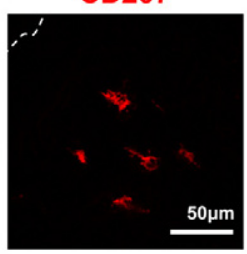

H-PGDS

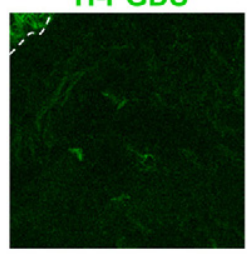

Merge
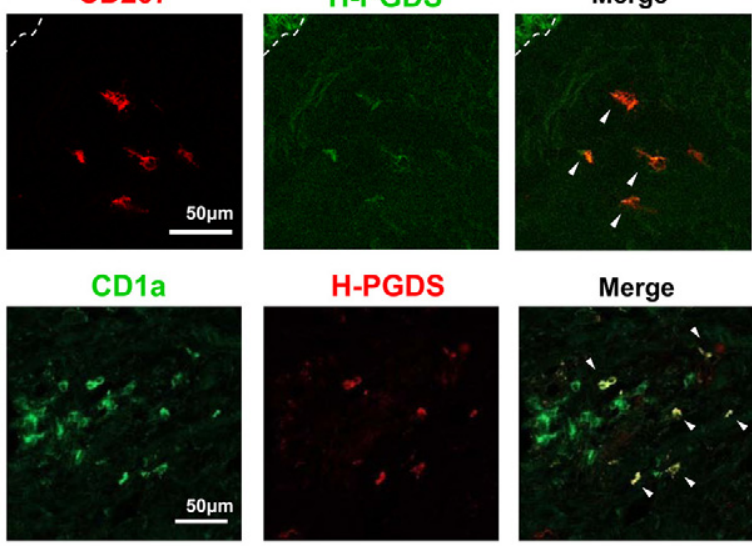

B

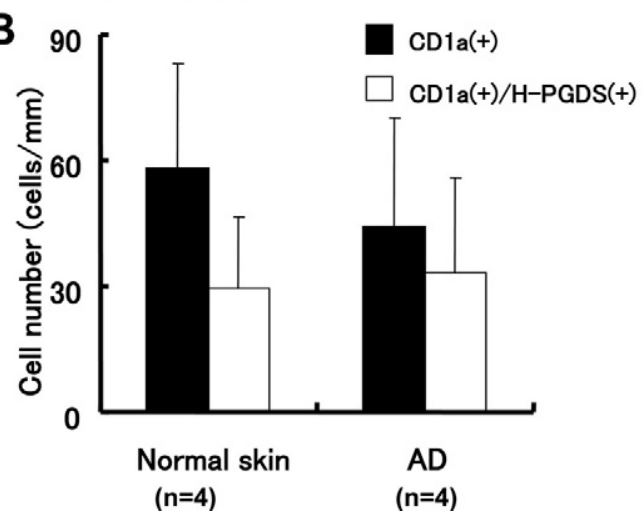

Figure 1. H-PGDS expression in epidermal Langerhans cells and dermal DCs. A: $\mathrm{H}-P G D S^{+}$cells in the epidermis of normal skin co-expressed CD1a (Langerhans cells) (upper panel). A small number of CD207 (Langerin ${ }^{+}$) cells expressing H-PGDS were found underneath the epidermis (middle panel, atopic dermatitis). There were also $\mathrm{CD}_{1} \mathrm{a}^{+}$cells expressing H-PGDS in the dermis (lower panel, atopic dermatitis). Solid lines indicate the cornified layer, and dashed lines indicate the dermo-epidermal junction. Arrowheads indicate cells expressing surface marker for DCs co-localized with H-PGDS. B: Prevalence of H-PGDS ${ }^{+}$epidermal Langerhans cells. AD denotes skin tissue specimens from patients with $\mathrm{AD}$

\section{Calcium lonophore Induces Rapid PGD2 Production from DCs}

We sought to determine the productive capability of PGD2 from DCs. Since sufficient numbers of pDCs and/or mDCs from blood or epidermal Langerhans cells from skin were not available, MoDCs were generated from $\mathrm{CD} 14^{+}$blood monocytes of healthy volunteers. We confirmed that MoDCs differentiated in vitro with GM-CSF/ interleukin-4 constitutively expressed H-PGDS mRNA without any stimulation, which was similar to pDCs and $\mathrm{mDCs}$ isolated from peripheral blood. In addition, the presence of H-PGDS protein was detected by both flow cytometric analysis and Western blotting (Figure $3 \mathrm{C}$ ). In the following experiments, verification of PGD2 gener- 
A
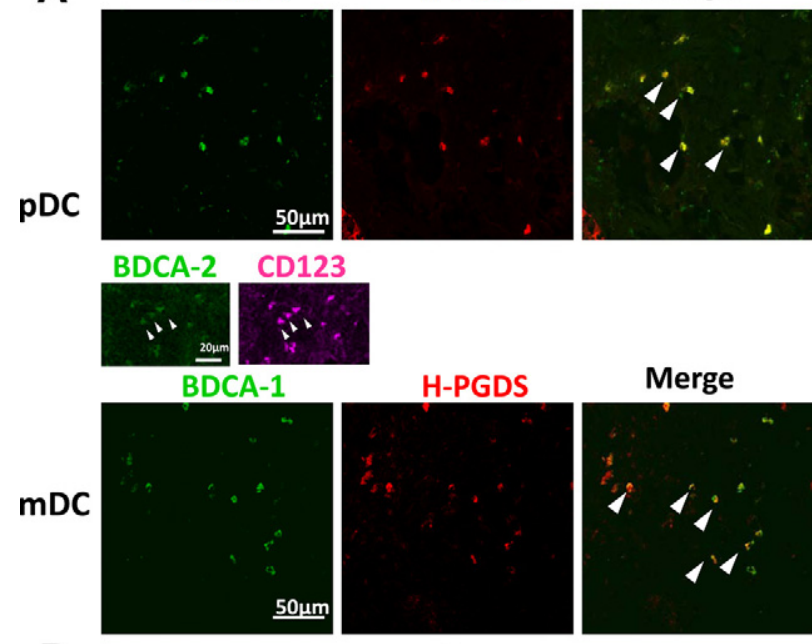

B
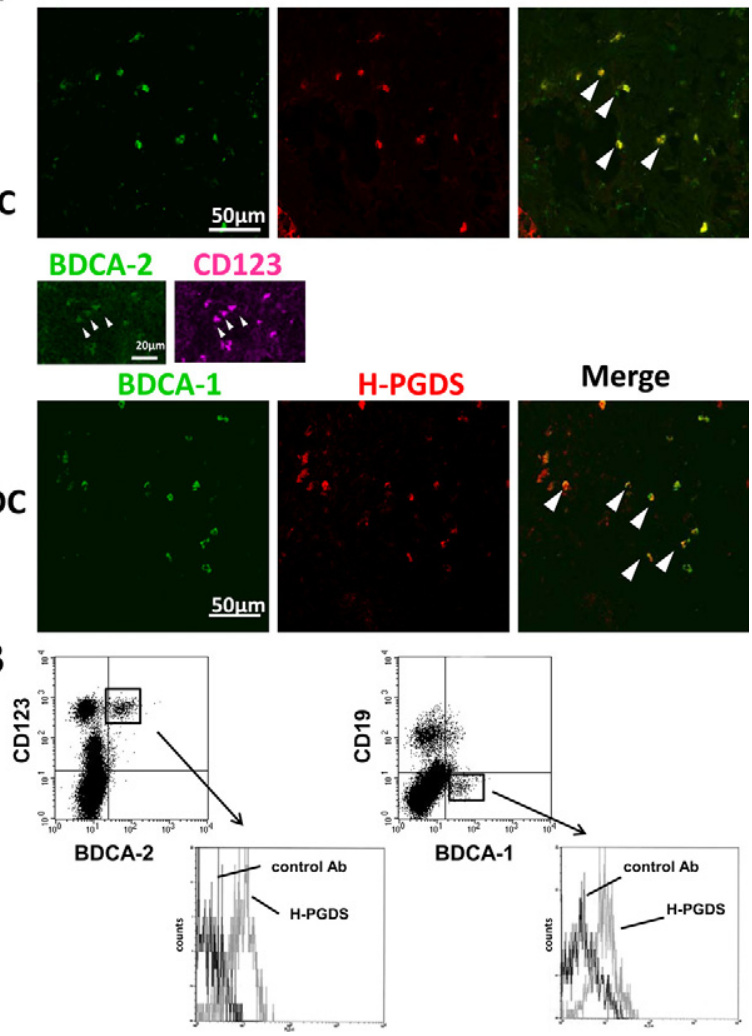

Merge

A

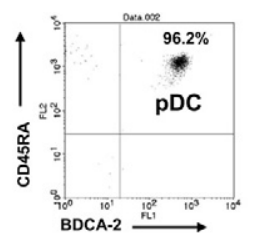

B

pDC

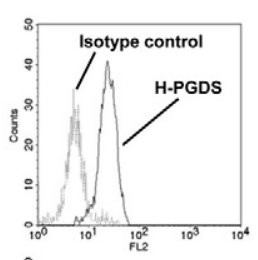

H-PGDS

$\beta$-actin

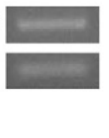

178bp

118bp

mDC

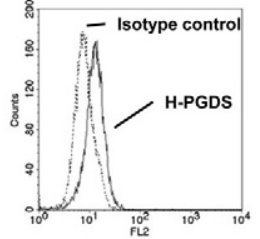

C

MoDC
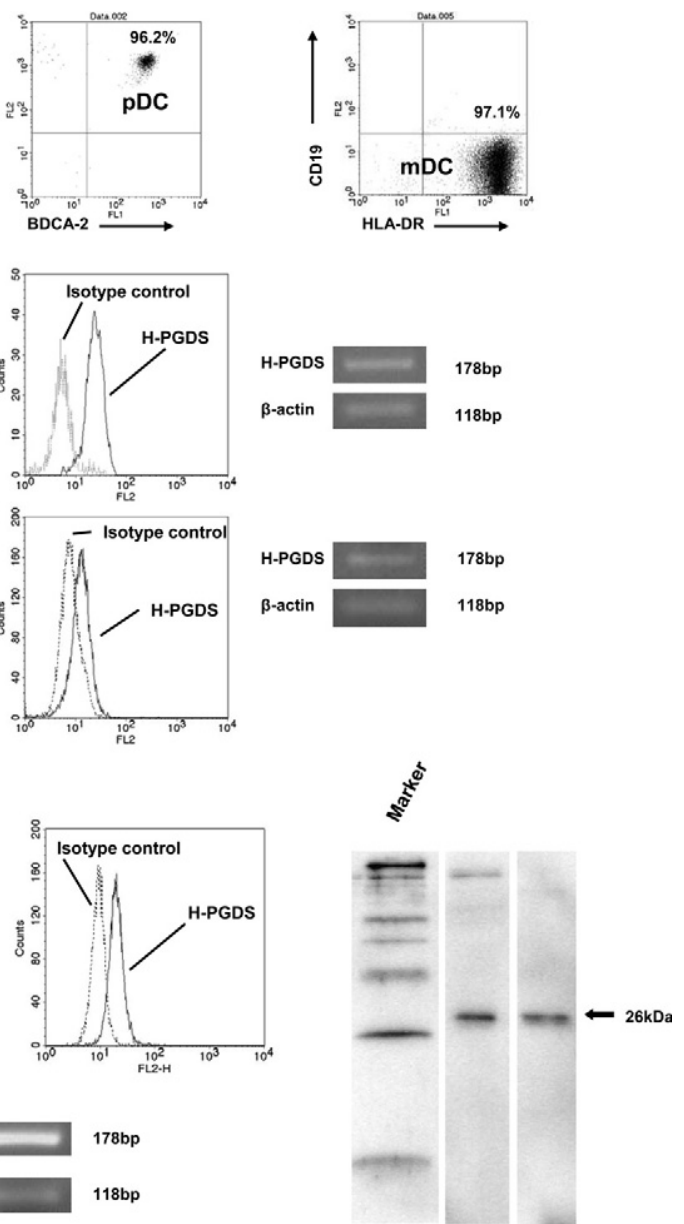

$\beta$-actin

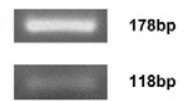

Figure 2. $\mathrm{H}-\mathrm{PGDS}$ expression in $\mathrm{pDCs}$ and mDCs. A: Skin tissues from patients with atopic dermatitis were stained with BDCA-2-FITC Ab, a specific marker for pDCs, or BDCA-1-FITC Ab, a specific marker for mDCs. H-PGDS was co-localized with BDCA- $2^{+}$and $\mathrm{BDCA}-1^{+}$pDCs and mDCs, respectively (arrowheads in upper and lower rows). pDCs were confirmed by positive staining for CD123 (arrowheads in the middle row). B: Flow cytometric analysis for intracellular H-PGDS in pDC and mDC with whole blood staining. pDCs and mDCs in whole blood were identified as CD $123^{+} / \mathrm{BDCA}-2^{+}$cells and $\mathrm{CD} 19^{-} / \mathrm{BDCA}-1^{+}$cells, respectively. Intracellular H-PGDS in these cells was detected by staining with polyclonal anti-human H-PGDS Ab.

ation by DCs was conducted with MoDCs prepared in vitro.

To investigate regulatory mechanisms of PGD2 production, we initially screened various substances and compounds for their ability to induce PGD2 production by DCs. In human megakaryoblastic cells, H-PGDS gene expression is stimulated by PMA (phorbol 12myrisate 13-acetate; Sigma Aldrich, Inc.). ${ }^{29}$ In MoDCs, although PMA increased mRNA synthesis of H-PGDS along with CPLA2, Cox-1, and Cox-2, extracellular PGD2 secretion was not induced by PMA even when cultured for up to 24 hours (Figure 4A). Human thymic stromal lymphopoietin (TSLP) activates DCs to induce effector T cells and/or to maintain $\mathrm{CRTH}_{2}{ }^{+}$Th2 cells. ${ }^{30,31}$ Thus, we attempted to stimulate DCs with TSLP ( $R$ and D Systems, Inc.). The TSLP treatment also stimulated the mRNA synthesis of these four enzymes; however, there was no statistically significant difference in the levels of extracellular PGD2 release between the stimulated cells and the medium control (Figure 4B).

Mast cells rapidly secrete PGD2 in response to calcium ionophore. ${ }^{22}$ Because PMA and TSLP failed to induce PGD2 secretion from MoDCs, we next examined

Figure 3. H-PGDS expression in isolated blood DCs. A: pDCs and mDCs were isolated from peripheral blood from normal donors by magnetic positive selection with CD304 (BDCA-4) for pDCs and with CD1c (BDCA-1) following the depletion of $\mathrm{CD} 19^{+}$cells for mDCs. We obtained high-purity cell suspensions (>95\%) as determined by the analysis of cell surface molecules, CD45RA and BDCA-2 for pDCs (left), and HLA-DR and CD19 for mDCs (right), respectively. B: Flow cytometric analysis (left) with the R-PE-conjugated mouse anti-H-PGDS mAb (EBC45) detected intracellular H-PGDS in pDCs and mDCs. RT-PCR analysis revealed the expression of H-PGDS mRNA in these cells (right). C: MoDCs generated from $\mathrm{CD} 14^{+}$-blood monocytes cultured with GM-CSF/interleukin-4 expressed intracellular H-PGDS as assessed by flow cytometry with EBC45 Ab. Western blotting analysis with the monoclonal anti-human H-PGDS $\mathrm{Ab}$ (1E6) confirmed the presence of intracellular H-PGDS. MoDCs constitutively expressed H-PGDS mRNA. The recombinant H-PGDS prepared at the Osaka Bioscience Institute was used as a positive control protein.

the capability of calcium ionophore to induce PGD2 secretion by DCs. As expected, there was a rapid and significant PGD2 secretion from MoDCs after stimulation with A23187 (Sigma Aldrich, Inc.) as assessed by Enzyme immunoassay (Figure 5A). The Thin-layer chromatography assay revealed that MoDCs secreted PGD2, but not PGE2 and PGF2 $\alpha$. PGD2 secretion was below the detection limit after 20 minutes, while arachidonic acid was persistently released for up to 60 minutes (Figure 5B). Interestingly, preincubation with PMA caused a significant enhancement of the A23187-induced rapid PGD2 secretion from MoDCs (Figure 5C), despite the fact that PMA alone did not induce PGD2 synthesis (Figure 4A). 

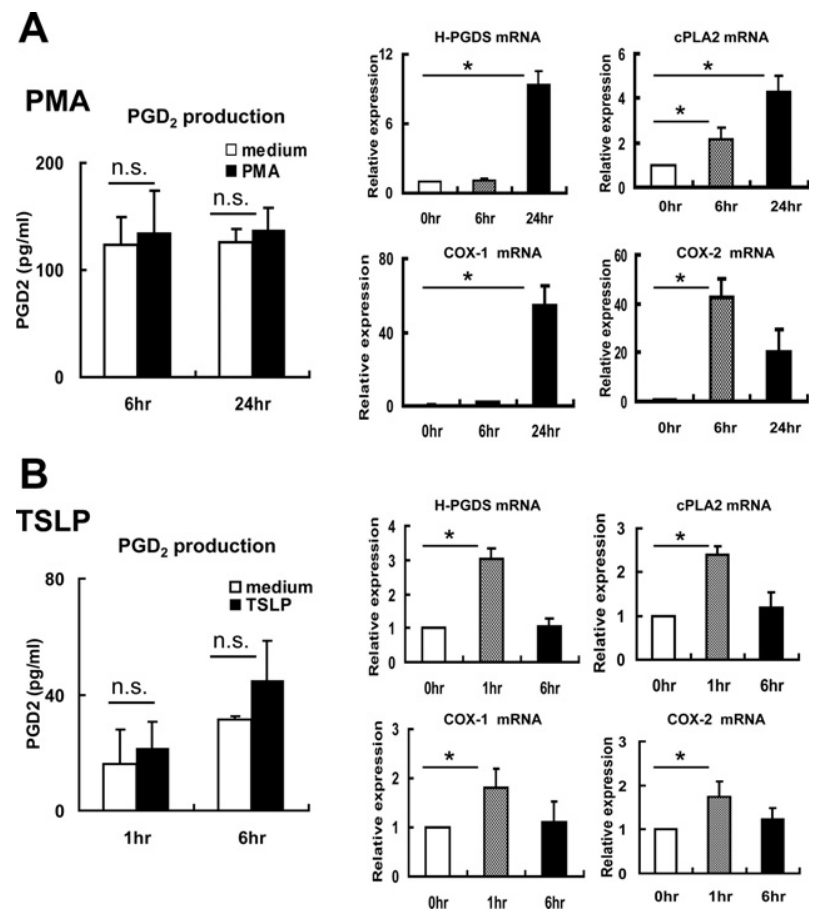

Figure 4. PMA and TSLP did not induce PGD2 secretion from MoDCs. MoDCs were incubated with (A) PMA $(1 \mu \mathrm{mol} / \mathrm{L})$ or (B) TSLP $(50 \mathrm{ng} / \mathrm{ml})$ for up to 24 hours. Neither of these stimuli induced PGD2 secretion, while mRNA expression of H-PGDS, cPLA2, Cox-1, and Cox-2 was elevated. Results after 6 and 24 hours of incubation with PMA and results after 1 and 6 hours of incubation with TSLP are shown, respectively. Experiments were repeated three times. ${ }^{*} P<0.05$.

\section{LPS Induces Delayed PGD2 Production from IFN- $\gamma$-Primed DCs}

LPS activates DCs and induces their maturation. ${ }^{32}$ In addition, LPS activates CPLA2, ${ }^{33}$ leading to the generation of PGE2. ${ }^{34}$ When MoDCs were stimulated with LPS (Escherichia coli, serotype O111:B4; Sigma Aldrich, Inc.), a small and delayed PGD2 production at 6 hours was observed (Figure 6A). This was accompanied by an increase in CPLA2 and Cox-2 mRNA and a dramatic reduction of H-PGDS mRNA expression. DCs exhibited cell maturation as assessed by the increased levels of surface HLA-DR and CD86, ${ }^{32}$ while intracellular H-PGDS protein was reduced by LPS stimulation (Figure 6B).

Notably, preincubation of MoDCs with IFN- $\gamma$ (100 $\mathrm{ng} / \mathrm{ml}$ ) (PeproTech) for 12 hours remarkably enhanced LPS-induced PGD2 secretion (Figure 6C). This effect was characterized by the inhibition of LPS-induced reduction of H-PGDS mRNA and by enhanced Cox-2 mRNA expression. The inhibition of LPS-induced reduction of H-PGDS was also confirmed by the Western blotting analysis (Figure 6C).

To further explore the mechanisms for synergistic effects of IFN- $\gamma$ on LPS-induced PGD2 release, we examined the expression levels of TLR4, a ligand for LPS. Preincubation with IFN- $\gamma$ caused an increase in TLR4 mRNA synthesis; however, the cell surface expression of TLR4 was not enhanced (Figure 6D). Thus,
A

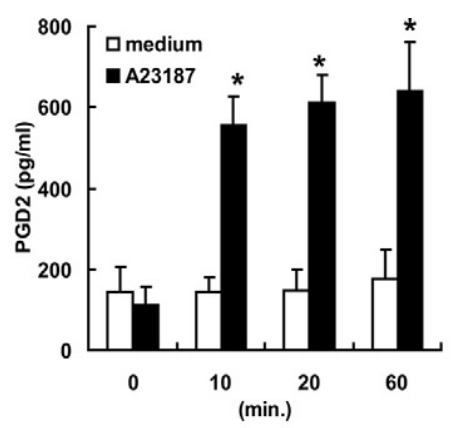

B
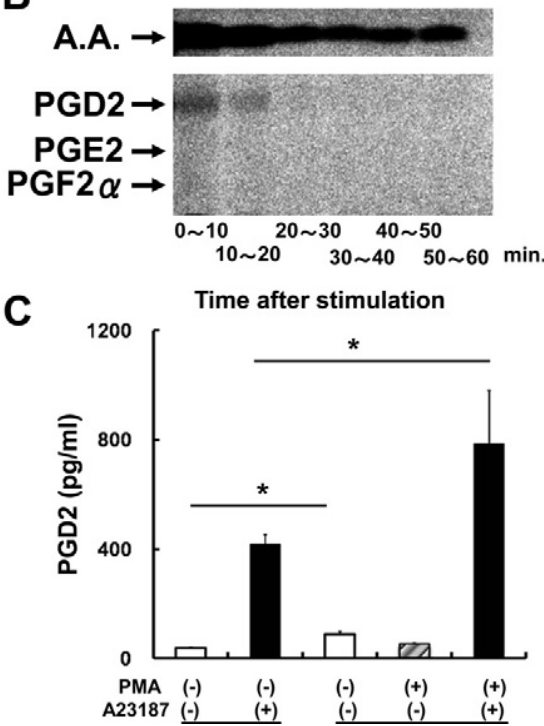

Figure 5. Calcium ionophore induced the rapid secretion of PGD2, but not PGE2, from MoDCs. A: MoDCs were incubated with the calcium ionophore A23187 $(5 \mu \mathrm{mol} / \mathrm{L})$ for the indicated periods. B: MoDCs prelabeled with $\left[1-{ }^{14} \mathrm{C}\right]$ arachidonic acid (A.A.) were stimulated with A23187. PGs secreted during each 10-minute interval were subjected to the TLC assay. PGD2 was produced as early as 10 minutes after stimulation and became undetectable after 20 minutes. Neither PGE2 nor PGF2 $\alpha$ was detected. C: (left) MoDCs were incubated with A23187 for 60 minutes; (right) MoDCs were incubated with PMA for 6 hours followed by stimulation with A23187 for 60 minutes. A23187 induced rapid PGD2 production (left, closed column) that was significantly enhanced by pretreatment with PMA for 6 hours (right closed column). MoDCs produced a small amount of PGD2 during the 6-hour incubation in medium alone (open column). Representative results of at least three separate experiments are shown. ${ }^{*} P<0.05$.

the priming effect of IFN- $\gamma$ was independent of cell surface TLR4 expression.

\section{DCs Release PGD2 in Response to an Irritant Chemical Compound}

Human skin is exposed to a variety of toxic and/or irritant materials. The barrier function of skin in patients with $A D$ is disrupted, and their skin is highly susceptible to an irritant chemical, SDS. ${ }^{35}$ In addition, SDS stimulates epidermal keratinocytes to secrete proinflammatory cytokines, such as interleukin- $1 \alpha$ and tumor necrosis factor- $\alpha .{ }^{36}$ Thus, we next characterized the effect of SDS (Wako Pure Chemical Industries, Osaka, Japan) on MoDCs. SDS dose-dependently induced PGD2 production at 1 hour (Figure 7A). Cell viability was not decreased, even at the highest doses of SDS, as assessed by propidium iodide staining (Sigma Aldrich, Inc.) (Figure 7B). Sustained cell 
A

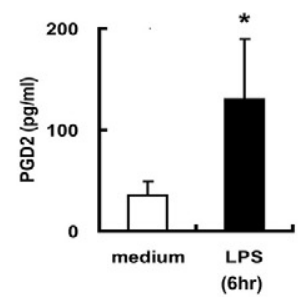

B
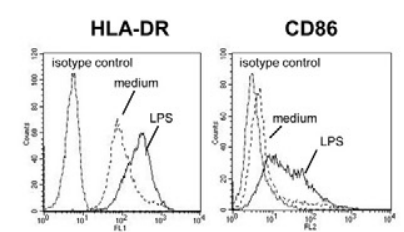

medium LPS

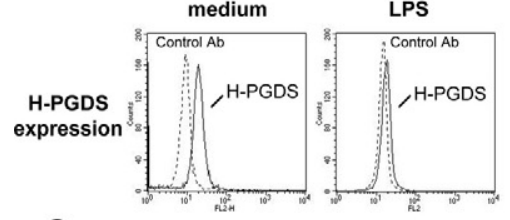

C

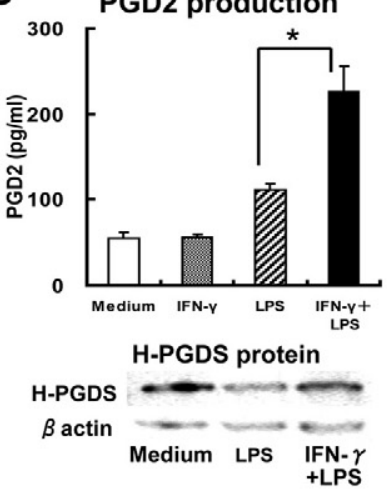

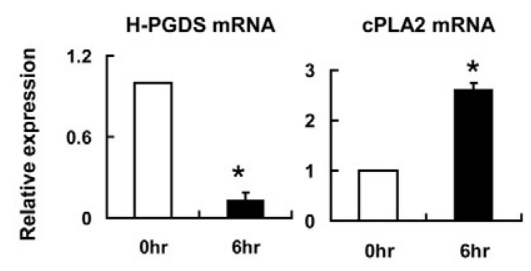

COX-1 mRNA

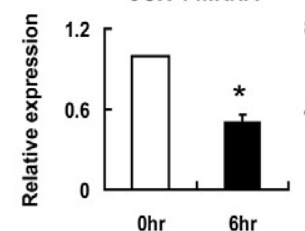

$6 \mathrm{hr}$

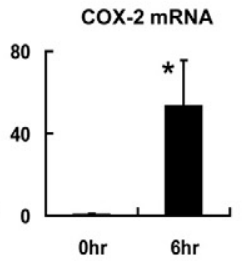

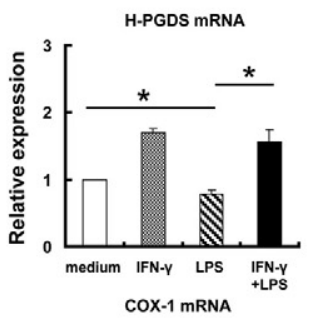

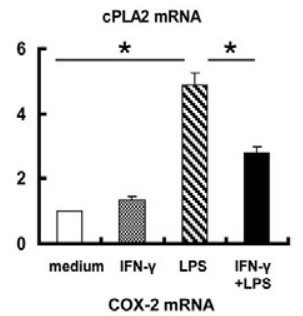

D
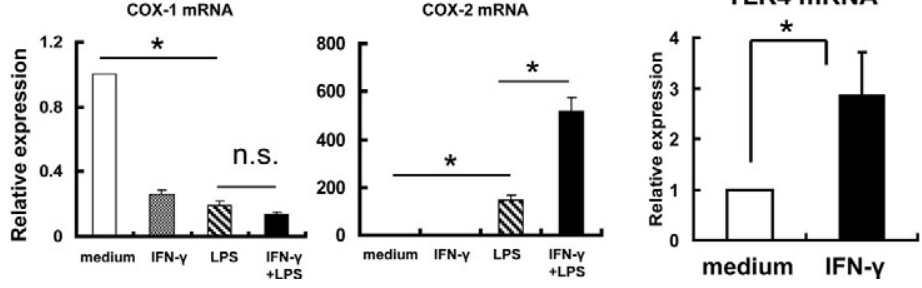

TLR4 expression

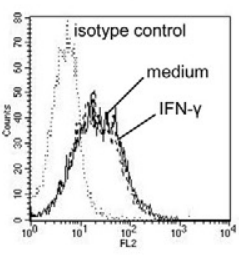

viability during a 1-hour incubation with SDS was also confirmed by 3-[4,5-dimethylthiazol-2-yl]-2,5-diphenyltetrazolium bromide (MTT) assay (CellTiter 96 Aqueous One Solution Cell Proliferation Assay, Promega Corp., Madison, WI) (data not shown).

\section{PGD2 Promotes CCL22/Macrophage-Derived Chemokine Expression in Human Keratinocytes Stimulated with IFN- $\gamma$}

Next, we examined the physiological relevance of DCderived PGD2. Given the evidence that LPS and/or SDS stimulated PGD2 release by DCs, we examined the effect of PGD2 on chemokine expression in human keratinocytes, which would be the cells directly exposed to PGD2 secreted from epidermal DCs (ie, Langerhans cells). In this context, we were interested in the generation of CCL22/macrophage-derived chemokine, as human lung epithelial cells produce CCL22/macrophage-derived chemokine in response to PGD2. ${ }^{37}$ Although PGD2 alone $(10 \mu \mathrm{mol} / \mathrm{L})$ (Cayman Chemicals) did not induce the synthesis of CCL22/macrophage-derived chemokine mRNA in human keratinocytes (data not shown), it synergisti-
Figure 6. Synergistic effect of IFN- $\gamma$ on delayed duced a small amount of PGD2 in response to LPS (1 $\mu \mathrm{g} / \mathrm{ml})$ at 6 hours. This production was accompanied by a significant enhancement of CPLA2 and Cox-2 mRNA and a marked reduction of H-PGDS mRNA expression. B: Intracellular H-PGDS (polyclonal anti-human H-PGDS Ab) decreased in response to LPS stimulation, while MoDCs exhibited cell maturation as demonstrated by the increased HLA-DR and CD86 expression. C: Preincubation with IFN- $\gamma(100 \mathrm{ng} / \mathrm{ml})$ for 12 hours synergistically promoted PGD2 secretion in response to LPS. IFN$\gamma$-pretreatment blocked the reduction of H-PGDS mRNA and protein synthesis and remarkably enhanced Cox-2 mRNA expression induced by LPS. D: IFN- $\gamma$ treatment for 12 hours caused an increase in TLR4 mRNA expression, but TLR4 expression on the cell surface of DCs was not enhanced by IFN- $\gamma$. Experiments were repeated at least three times. ${ }^{*} P<0.05$.

cally enhanced IFN- $\gamma$-induced CCL22/macrophage-derived chemokine mRNA expression (Figure 8).

\section{DCs Generating PGD2 Promote the Production of Interleukin-17 from Lymphocytes}

We further attempted to identify the biological significance of DC-derived PGD2. To this end, we compared the stimulatory capabilities of DNP-DCs from wild-type mice and mice lacking the H-PGDS gene. LN cells used as responder cells were obtained from $\mathrm{H}-\mathrm{PGDS}^{-1-}$ mice sensitized with 2,4-dinitrofluorobenzene to minimize the PGD2 production from these cells. DNP-DC from wildtype mice exhibited a small and spontaneous secretion of PGD2 (Figure 9, upper left), as seen in human cultured MoDCs. Co-incubation of the DCs with LN cells from $\mathrm{H}_{-\mathrm{PGDS}}{ }^{-1-}$ mice significantly enhanced PGD2 levels. Interestingly, LN cells produced higher amounts of interleukin-17 when stimulated with DNP-DC from wild-type mice than with DNP-DC from H-PGDS ${ }^{-1-}$ mice (Figure 9, lower right). The levels of interleukin- 4 and IFN- $\gamma$ were comparable with each other. 
A

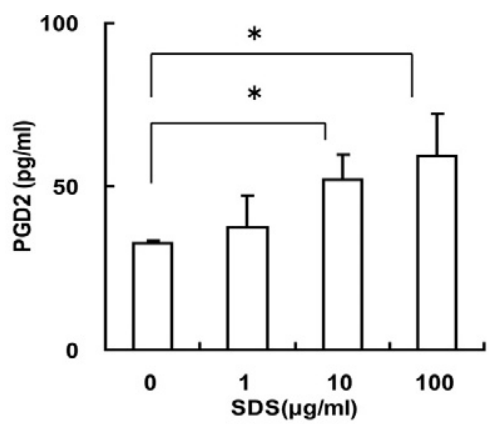

B

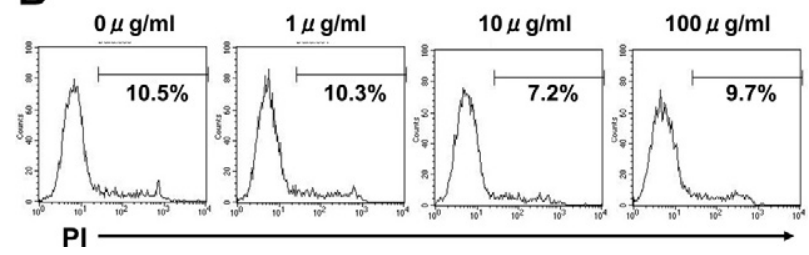

Figure 7. PGD2 release by MoDCs stimulated with an irritant SDS. A: MoDCs were incubated with SDS at the indicated dose for 1 hour. PGD2 was dose-dependently released from MoDCs in response to SDS. B: SDS treatment at concentrations up to $100 \mu \mathrm{g} / \mathrm{ml}$ did not reduce cell viability, as assessed by propidium iodide. Representative results of three separate experiments are shown. ${ }^{*} P<0.05$.

\section{Discussion}

In this study, we demonstrated that a variety of human DCs, such as epidermal Langerhans cells, dermal DCs, pDCs, and mDCs, express H-PGDS. In addition, we clarified the regulatory mechanisms of PGD2 production by MoDCs in vitro. The amount of PGD2 secreted from DCs was 100 times less than the amount secreted by mast cells and 20 times less than the amount secreted by Th2 cells. ${ }^{22,23,25}$ Nevertheless, epidermal DCs, such as Langerhans cells, should be a major source of PGD2 in the epidermis. In addition, DC-derived PGD2 directly influences the function of lymphocytes during antigen presentation. Indeed, murine DCs producing PGD2 promoted interleukin-17 generation from lymph node cells in vitro.

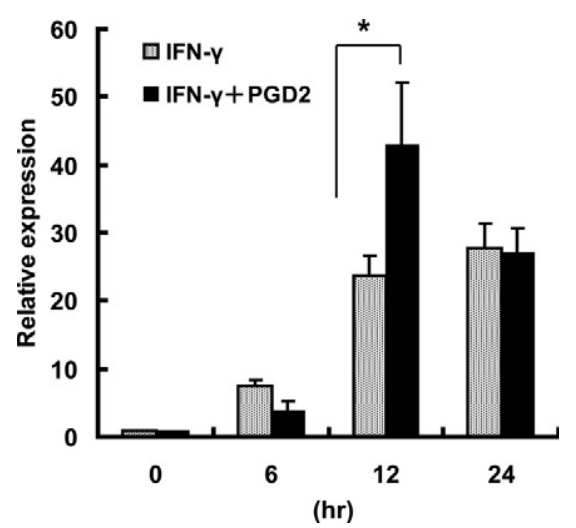

Figure 8. Synergistic effects of PGD2 and IFN- $\gamma$ on CCL22/macrophagederived chemokine expression in keratinocytes. Normal human keratinocytes were stimulated for the indicated periods with IFN- $\gamma(10 \mathrm{ng} / \mathrm{ml})$ and/or PGD2 (10 $\mu \mathrm{mol} / \mathrm{L})$. PGD2 significantly enhanced CCL22/macrophage-derived chemokine mRNA synthesis in keratinocytes stimulated with IFN- $\gamma$. Representative results of two separate experiments are shown. ${ }^{*} P<0.05$.
While H-PGDS was detected in almost all epidermal Langerhans cells in mouse skin, ${ }^{7}$ only about half of human Langerhans cells express H-PGDS (Figure 1B). In this respect, it was interesting to note that intracellular H-PGDS levels in MoDCs decreased along with their maturation induced by LPS (Figure 6B). Although the mechanisms responsible for the rapid loss of immunoreactive H-PGDS in DCs are uncertain, the prevalence of

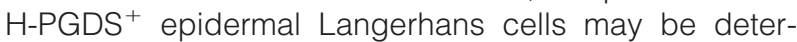
mined by their maturation, which is induced by environmental stimulation or influenced by the turnover rate of epidermal Langerhans cells.

In mast cells, aggregation of FceRl by IgE or calcium ionophore A23187 induced a rapid secretion of PGD2 within 10 to 20 minutes after stimulation. ${ }^{22}$ This secretion is mediated by the activation of phospholipase A2, resulting in the release of arachidonic acids. ${ }^{23}$ Similarly, in the present study, MoDCs exhibited a rapid secretion of PGD2 in response to A23187. Secretion of PGD2 assessed by EIA was detected as early as 10 minutes. The TLC assay confirmed the secretion of PGD2 from MoDCs, and it also revealed that MoDCs treated with calcium ionophore did not generate PGE2. Unknown mechanisms control the enzymatic cascade that favors the activation of H-PGDS rather than PGE synthase after the influx of $\mathrm{Ca}^{+}$and release of arachidonic acid. More importantly, PGD2 secretion decreased within 20 minutes despite the persistent release of arachidonic acid (Figure 5B). An additional study is needed to elucidate the mechanisms underlying the rapid inactivation of H-PGDS within 20 minutes in the presence of arachidonic acids.

PMA stimulates the expression of the H-PGDS gene in human megakaryoblastic cells. ${ }^{29}$ Consistent with this observation, MoDCs stimulated with PMA showed increased expression of H-PGDS mRNA (Figure 4A). However, PGD2 secretion did not occur despite the fact that the increase in H-PGDS mRNA was accompanied by cPLA2, Cox-2, and Cox-1 mRNA expression. In contrast, pretreatment of MoDCs with PMA synergistically enhanced the A23187-induced rapid secretion of PGD2 (Figure $5 \mathrm{C}$ ). The priming effect by PMA could be obtained by the increased levels of CPLA2, Cox-1/2, and $\mathrm{H}$-PGDS, enabling the promotion of the enzymatic cascade for PGD2 synthesis, such as arachidonic acid release, PGH2 generation, and isomerization, by these enzymes, respectively, when the $\mathrm{Ca}_{2}{ }^{+}$influx was subsequently induced by A23187.

LPS stimulation induced the delayed production of PGD2, which was not marked but was statistically significant. This result is in striking contrast to a prior report demonstrating a lack of PGD2 secretion from MoDCs stimulated with LPS. ${ }^{34}$ This discrepancy may be explained by differences in E. coli, in the serotype of LPS (0111:B4 versus 055:B5), or in the concentration of LPS $(1 \mu \mathrm{g} / \mathrm{ml}$ versus $100 \mathrm{ng} / \mathrm{ml})$. In addition, we stimulated MoDCs with LPS in the presence of GM-CSF/interleukin-4. The delayed and long-lasting secretion of PGD2 could be partly mediated by the slow and persistent activation of CPLA2 by LPS. ${ }^{33}$ Unlike the stimulation with A23187, we detected PGE2 production from MoDCs in response to LPS $(78.1 \pm 8.94 \mathrm{pg} / \mathrm{ml}$ for medium and 

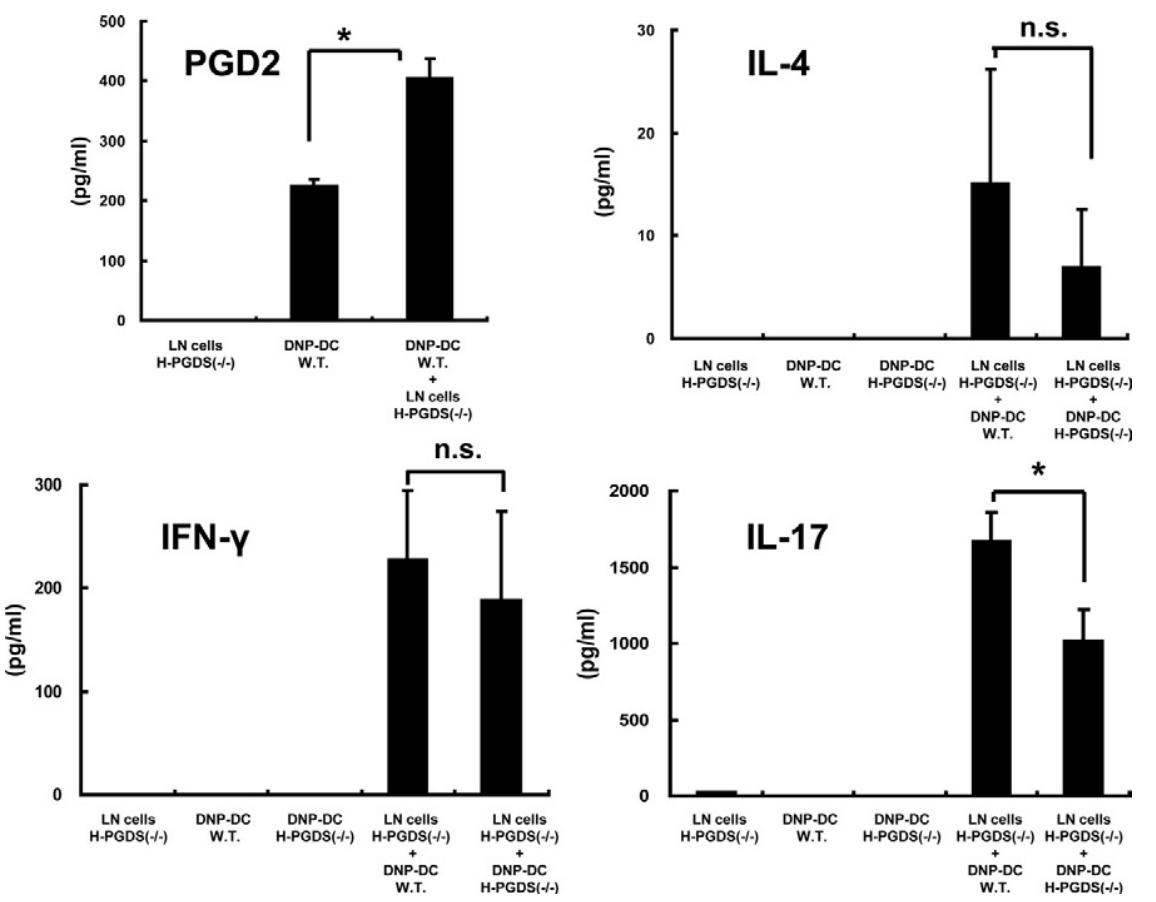

Figure 9. DCs capable of generating PGD2 promote interleukin-17 production from lymphocytes. Immune LN cells were obtained from $\mathrm{H}_{-\mathrm{PGDS}}{ }^{-/-}$mice and stimulated with DNP-DCs from either wild type (W.T.) or H-PGDS ${ }^{-1}$ mice for 24 hours in vitro. PGD2 and cytokine levels in the supernatants were measured. Representative results of two separate experiments are shown. ${ }^{*} P<0.05$.
$178.7 \pm 26.90 \mathrm{pg} / \mathrm{ml}$ for LPS, respectively), which is consistent with a prior report. ${ }^{34}$

Pretreatment with IFN- $\gamma$ significantly enhanced PGD2 production by LPS. IFN- $\gamma$ enhances TLR4 expression by DCs during stimulation for 48 hours. ${ }^{38}$ However, in this experiment where MoDCs were stimulated for 12 hours, IFN- $\gamma$ treatment did not enhance TLR4 expression (Figure 6D). Thus, the mechanisms responsible for the priming effect of IFN- $\gamma$ were likely to result from synergism of intracellular events mediated by IFN- $\gamma$ and LPS rather than the increased expression of LPS ligand. In general, the functional relationship between IFN- $\gamma$ - and LPS-mediated signaling events is in argument. The suppressor of cytokine signaling, which is a key molecule for IFN- $\gamma$ signaling, directly inhibits TLR4 signaling. ${ }^{39,40}$ Nevertheless, IFN- $\gamma$ enhances LPS-induced DC maturation and cytokine production. ${ }^{41}$ In addition, IFN- $\gamma$ and LPS have a synergism in the interleukin-27 p28 gene of macrophages $^{42}$ and in the interleukin-23 p19 gene of CD11c ${ }^{+}$ myeloid antigen-presenting cells. ${ }^{43}$ In the present study, IFN- $\gamma$ priming resulted in synergistic enhancement of LPS-induced Cox-2 expression and inhibition of LPSinduced reduction in H-PGDS; these pathways seem to be a mechanism of IFN- $\gamma$-mediated enhancement of PGD2 secretion in response to LPS. PGD2 released by IFN- $\gamma$-primed DCs in response to LPS presented by environmental bacteria may affect the immune responses in chronic skin lesions of patients with $A D$, as the production of IFN- $\gamma$, a Th1-type cytokine, is elevated in chronic skin lesions, while Th2-type cytokines are dominant in acute lesions of patients with AD. ${ }^{44,45}$ IFN- $\gamma$-mediated enhancement of PGD2 production has also been demonstrated in human Langerhans cells stimulated with nicotinic acid because of the enhancement of the nicotinic acid receptor by IFN- $\gamma$ treatment. ${ }^{46}$
We noted a minimal increase in the basal levels of PGD2 secreted from MoDCs during the 6 hours of culture with medium containing GM-CSF/interleukin-4 (Figures $4 \mathrm{~B}$ and $5 \mathrm{C}$, open columns). These data suggest that GM-CSF/interleukin-4 not only sustained cell differentiation toward DCs, but also stimulated MoDCs to persistently produce a small amount of PGD2. Alternatively, a trace amount of endotoxin contamination in the culture medium might cause PGD2 secretion. The levels of PGD2 reached a peak level at 6 hours, and no further increases were detected after 12 and 24 hours of incubation (Figure 4A, open columns). This result was probably due to the nonenzymatic degradation of PGD2 in the culture medium.

Epidermal keratinocytes are capable of secreting proinflammatory cytokines, interleukin- $1 \alpha$ and tumor necrosis factor- $\alpha$, in response to an irritant chemical, SDS, ${ }^{36}$ although it did not have any effect on cytokine release by DCs. ${ }^{47}$ In the present study, we found that SDS stimulated MoDCs to release PGD2. These findings are intriguing since the skin of patients with $A D$ is susceptible to contact with SDS because of the impaired skin barrier function. ${ }^{48,35}$ In addition, in the present study, we showed that IFN- $\gamma$ stimulated CCL22/macrophage-derived chemokine mRNA expression in human keratinocytes, which was synergistically enhanced by PGD2. These data could be important in terms of physiological relevance to skin inflammation, in particular, chronic skin lesions of $A D$ where IFN- $\gamma$ is produced, because PGD2 secreted from epidermal DCs may directly act on neighboring keratinocytes. CCL22/macrophage-derived chemokine functions as an chemoattractant for $\mathrm{CCR} 4^{+}$cells, such as Th2 cells, ${ }^{49}$ and IFN- $\gamma$-mediated CCL22/macrophage-derived chemokine production together with Th1-type che- 
mokine generation ${ }^{50}$ has been implicated in the pathogenesis of chronic skin lesions of AD. ${ }^{51}$

PGD2 generation from murine DCs was stimulated by co-incubation with LN cells. In addition, DCs from wildtype mice were more potent than DCs from $\mathrm{H}_{-} \mathrm{PGDS}^{-/-}$ mice in respect to stimulating interleukin-17 generation from $L N$ cells, which demonstrates additional physiological relevance of DC-derived PGD2 in inflammation. Obviously, immunological events in mice are not necessarily relevant to human systems, but these data suggest that PGD2 from DCs could affect T-cell expansion and/or modification of cytokine profiles in some of the inflammatory reactions.

Collectively, DCs in the epidermis and dermis are capable of functioning as an important source of PGD2 in the skin, thereby contributing to or regulating innate and/or acquired immune responses of the skin.

\section{References}

1. Nagoshi H, Uehara Y, Kanai F, Maeda S, Ogura T, Goto A, Toyo-oka T, Esumi H, Shimizu T, Omata M: Prostaglandin D2 inhibits inducible nitric oxide synthase expression in rat vascular smooth muscle cells. Circ Res 1998, 82:204-209

2. Narumiya S, Toda N: Different responsiveness of prostaglandin D2sensitive systems to prostaglandin D2 and its analogues. Br J Pharmacol 1985, 85:367-375

3. Beasley CR, Robinson C, Featherstone RL, Varley JG, Hardy CC, Church MK, Holgate ST: 9 alpha, 11 beta-prostaglandin F2, a novel metabolite of prostaglandin D2 is a potent contractile agonist of human and guinea pig airways. J Clin Invest 1987, 79:978-983

4. Whittle BJ, Moncada S, Vane JR: Comparison of the effects of prostacyclin (PGI2), prostaglandin E1 and D2 on platelet aggregation in different species. Prostaglandins 1978, 16:373-388

5. Miadonna A, Tedeschi A, Brasca C, Folco G, Sala A, Murphy RC: Mediator release after endobronchial antigen challenge in patients with respiratory allergy. J Allergy Clin Immunol 1990, 85:906-913

6. Fujitani Y, Kanaoka Y, Aritake K, Uodome N, Okazaki-Hatake K, Urade $Y$ : Pronounced eosinophilic lung inflammation and Th2 cytokine release in human lipocalin-type prostaglandin $\mathrm{D}$ synthase transgenic mice. J Immunol 2002, 168:443-449

7. Satoh $T$, Moroi R, Aritake K, Urade $\mathrm{Y}$, Kanai $\mathrm{Y}$, Sumi K, Yokozeki $\mathrm{H}$, Hirai H, Nagata K, Hara T, Utsuyama M, Hirokawa K, Sugamura K, Nishioka K, Nakamura M: Prostaglandin D2 plays an essential role in chronic allergic inflammation of the skin via CRTH2 receptor. J Immunol 2006, 177:2621-2629

8. Sugimoto M, Arai I, Futaki N, Hashimoto $Y$, Sakurai T, Honma $Y$, Nakaike S: The anti-pruritic efficacy of TS-022, a prostanoid DP1 receptor agonist, is dependent on the endogenous prostaglandin D2 level in the skin of NC/Nga mice. Eur J Pharmacol 2007, 564:196-203

9. Sugimoto M, Arai I, Futaki N, Honma Y, Sakurai T, Hashimoto Y, Nakaike S: Putative mechanism of the itch-scratch circle: repeated scratching decreases the cutaneous level of prostaglandin D2, a mediator that inhibits itching. Prostaglandins Leukot Essent Fatty Acids 2007, 76:93-101

10. Hirai H, Tanaka K, Yoshie O, Ogawa K, Kenmotsu K, Takamori Y, Ichimasa M, Sugamura K, Nakamura M, Takano S, Nagata K: Prostaglandin D2 selectively induces chemotaxis in T helper type 2 cells, eosinophils, and basophils via seven-transmembrane receptor CRTH2. J Exp Med 2001, 193:255-261

11. Angeli V, Staumont D, Charbonnier AS, Hammad H, Gosset P, Pichavant M, Lambrecht BN, Capron M, Dombrowicz D, Trottein F: Activation of the $D$ prostanoid receptor 1 regulates immune and skin allergic responses. J Immunol 2004, 172:3822-3829

12. Angeli V, Faveeuw C, Roye O, Fontaine J, Teissier E, Capron A, Wolowczuk I, Capron M, Trottein F: Role of the parasite-derived prostaglandin D2 in the inhibition of epidermal Langerhans cell migration during schistosomiasis infection. J Exp Med 2001, 193:1135-1147

13. Hammad H, de Heer HJ, Soullie T, Hoogsteden HC, Trottein F,
Lambrecht BN: Prostaglandin D2 inhibits airway dendritic cell migration and function in steady state conditions by selective activation of the D prostanoid receptor 1. J Immunol 2003, 171:3936-3940

14. Gosset P, Bureau F, Angeli V, Pichavant M, Faveeuw C, Tonnel AB, Trottein F: Prostaglandin D2 affects the maturation of human monocyte-derived dendritic cells: consequence on the polarization of naive Th cells. J Immunol 2003, 170:4943-4952

15. Tanaka K, Hirai H, Takano S, Nakamura M, Nagata K: Effects of prostaglandin D2 on helper T cell functions. Biochem Biophys Res Commun 2004, 316:1009-1014

16. Kanaoka Y, Urade Y: Hematopoietic prostaglandin D synthase. Prostaglandins Leukot Essent Fatty Acids 2003, 69:163-167

17. Urade $\mathrm{Y}$, Eguchi N: Lipocalin-type and hematopoietic prostaglandin D synthases as a novel example of functional convergence. Prostaglandins Other Lipid Mediat 2002, 68-69:375-382

18. Urade $\mathrm{Y}$, Hayaishi O: Prostaglandin D2 and sleep regulation. Biochim Biophys Acta 1999, 1436:606-615

19. Christ-Hazelhof E, Nugteren DH: Purification and characterisation of prostaglandin endoperoxide D-isomerase, a cytoplasmic, glutathione-requiring enzyme. Biochim Biophys Acta 1979, 572:43-51

20. Urade Y, Fujimoto N, Ujihara M, Hayaishi O: Biochemical and immunological characterization of rat spleen prostaglandin $\mathrm{D}$ synthetase. J Biol Chem 1987, 262:3820-3825

21. Urade $Y$, Ujihara $M$, Horiguchi $Y$, Igarashi $M$, Nagata $A$, Ikai $K$, Hayaishi O: Mast cells contain spleen-type prostaglandin D synthetase. J Biol Chem 1990, 265:371-375

22. Lewis RA, Soter NA, Diamond PT, Austen KF, Oates JA, Roberts LJ, 2nd: Prostaglandin D2 generation after activation of rat and human mast cells with anti-IgE. J Immunol 1982, 129:1627-1631

23. Peters SP, MacGlashan DW Jr, Schulman ES, Schleimer RP, Hayes EC, Rokach J, Adkinson NF Jr, Lichtenstein LM: Arachidonic acid metabolism in purified human lung mast cells. J Immunol 1984, 132:1972-1979

24. Naclerio RM, Proud D, Togias AG, Adkinson NF Jr, Meyers DA, Kagey-Sobotka A, Plaut M, Norman PS, Lichtenstein LM: Inflammatory mediators in late antigen-induced rhinitis. N Engl J Med 1985, 313:65-70

25. Tanaka K, Ogawa K, Sugamura K, Nakamura M, Takano S, Nagata K: Cutting edge: differential production of prostaglandin D2 by human helper T cell subsets. J Immunol 2000, 164:2277-2280

26. Ujihara M, Horiguchi Y, Ikai K, Urade Y: Characterization and distribution of prostaglandin $D$ synthetase in rat skin. $J$ Invest Dermatol 1988, 90:448-451

27. Urade $Y$, Ujihara M, Horiguchi $Y$, Ikai K, Hayaishi O: The major source of endogenous prostaglandin D2 production is likely antigen-presenting cells: localization of glutathione-requiring prostaglandin D synthetase in histiocytes, dendritic, and Kupffer cells in various rat tissues. J Immunol 1989, 143:2982-2989

28. Trivedi SG, Newson J, Rajakariar R, Jacques TS, Hannon R, Kanaoka Y, Eguchi N, Colville-Nash P, Gilroy DW: Essential role for hematopoietic prostaglandin D2 synthase in the control of delayed type hypersensitivity. Proc Natl Acad Sci USA 2006, 103:5179-5184

29. Fujimori K, Kanaoka Y, Sakaguchi Y, Urade Y: Transcriptional activation of the human hematopoietic prostaglandin $D$ synthase gene in megakaryoblastic cells: roles of the oct-1 element in the $5^{\prime}$-flanking region and the AP-2 element in the untranslated exon 1. J Biol Chem 2000, 275:40511-40516

30. Wang YH, Ito T, Homey B, Watanabe N, Martin R, Barnes CJ, Mclntyre BW, Gilliet M, Kumar R, Yao Z, Liu YJ: Maintenance and polarization of human TH2 central memory T cells by thymic stromal lymphopoietinactivated dendritic cells. Immunity 2006, 24:827-838

31. Watanabe N, Hanabuchi S, Marloie-Provost MA, Antonenko S, Liu YJ, Soumelis V: Human TSLP promotes CD40 ligand-induced IL-12 production by myeloid dendritic cells but maintains their Th2 priming potential. Blood 2005, 105:4749-4751

32. Spisek R, Brazova J, Rozkova D, Zapletalova K, Sediva A, Bartunkova $\mathrm{J}$ : Maturation of dendritic cells by bacterial immunomodulators. Vaccine 2004, 22:2761-2768

33. Qi HY, Shelhamer JH: Toll-like receptor 4 signaling regulates cytosolic phospholipase A2 activation and lipid generation in lipopolysaccharidestimulated macrophages. J Biol Chem 2005, 280:38969-38975

34. Fogel-Petrovic M, Long JA, Knight DA, Thompson PJ, Upham JW: Activated human dendritic cells express inducible cyclo-oxygenase 
and synthesize prostaglandin E2 but not prostaglandin D2. Immunol Cell Biol 2004, 82:47-54

35. Tabata N, Tagami H, Kligman AM: A twenty-four-hour occlusive exposure to $1 \%$ sodium lauryl sulfate induces a unique histopathologic inflammatory response in the xerotic skin of atopic dermatitis patients. Acta Derm Venereol 1998, 78:244-247

36. Miyazaki Y, Yokozeki H, Awad S, Igawa K, Minatohara K, Satoh T, Katayama I, Nishioka K: Glucocorticoids augment the chemically induced production and gene expression of interleukin-1alpha through NF-kappaB and AP-1 activation in murine epidermal cells. J Invest Dermatol 2000, 115:746-752

37. Honda K, Arima M, Cheng G, Taki S, Hirata H, Eda F, Fukushima F, Yamaguchi B, Hatano M, Tokuhisa T, Fukuda T: Prostaglandin D2 reinforces Th2 type inflammatory responses of airways to low-dose antigen through bronchial expression of macrophage-derived chemokine. J Exp Med 2003, 198:533-543

38. Frasca L, Nasso M, Spensieri F, Fedele G, Palazzo R, Malavasi F, Ausiello CM: IFN-gamma arms human dendritic cells to perform multiple effector functions. J Immunol 2008, 180:1471-1481

39. Kinjyo I, Hanada T, Inagaki-Ohara K, Mori H, Aki D, Ohishi M, Yoshida $\mathrm{H}$, Kubo M, Yoshimura $\mathrm{A}$ : SOCS1/JAB is a negative regulator of LPS-induced macrophage activation. Immunity 2002, 17:583-591

40. Nakagawa R, Naka T, Tsutsui H, Fujimoto M, Kimura A, Abe T, Seki E, Sato S, Takeuchi O, Takeda K, Akira S, Yamanishi K, Kawase I, Nakanishi K, Kishimoto T: SOCS-1 participates in negative regulation of LPS responses. Immunity 2002, 17:677-687

41. Strengell M, Lehtonen A, Matikainen S, Julkunen I: IL-21 enhances SOCS gene expression and inhibits LPS-induced cytokine production in human monocyte-derived dendritic cells. J Leukoc Biol 2006, 79:1279-1285

42. Liu J, Guan X, Ma X: Regulation of IL-27 p28 gene expression in macrophages through MyD88- and interferon-gamma-mediated pathways. J Exp Med 2007, 204:141-152

43. Kryczek I, Bruce AT, Gudjonsson JE, Johnston A, Aphale A, Vatan L, Szeliga W, Wang Y, Liu Y, Welling TH, Elder JT, Zou W: Induction of
IL-17+ T cell trafficking and development by IFN-gamma: mechanism and pathological relevance in psoriasis. J Immunol 2008, 181:4733-4741

44. Grewe M, Gyufko K, Schopf E, Krutmann J: Lesional expression of interferon-gamma in atopic eczema. Lancet 1994, 343:25-26

45. Tsicopoulos A, Hamid Q, Haczku A, Jacobson MR, Durham SR, North J, Barkans J, Corrigan CJ, Meng Q, Moqbel R, Kay AB: Kinetics of cell infiltration and cytokine messenger RNA expression after intradermal challenge with allergen and tuberculin in the same atopic individuals. J Allergy Clin Immunol 1994, 94:764-772

46. Maciejewski-Lenoir D, Richman JG, Hakak Y, Gaidarov I, Behan DP, Connolly DT: Langerhans cells release prostaglandin D2 in response to nicotinic acid. J Invest Dermatol 2006, 126:2637-2646

47. Coutant KD, de Fraissinette AB, Cordier A, Ulrich P: Modulation of the activity of human monocyte-derived dendritic cells by chemical haptens, a metal allergen, and a staphylococcal superantigen. Toxicol Sci 1999, 52:189-198

48. Loffler H, Effendy I: Skin susceptibility of atopic individuals. Contact Dermatitis 1999, 40:239-242

49. Imai T, Nagira M, Takagi S, Kakizaki M, Nishimura M, Wang J, Gray PW, Matsushima K, Yoshie O: Selective recruitment of CCR4-bearing Th2 cells toward antigen-presenting cells by the CC chemokines thymus and activation-regulated chemokine and macrophage-derived chemokine. Int Immunol 1999, 11:81-88

50. Tensen CP, Flier J, Van Der Raaij-Helmer EM, Sampat-Sardjoepersad S, Van Der Schors RC, Leurs R, Scheper RJ, Boorsma DM, Willemze R: Human IP-9: a keratinocyte-derived high affinity CXC-chemokine ligand for the IP-10/Mig receptor (CXCR3). J Invest Dermatol 1999, 112:716-722

51. Horikawa T, Nakayama T, Hikita I, Yamada H, Fujisawa R, Bito T, Harada S, Fukunaga A, Chantry D, Gray PW, Morita A, Suzuki R, Tezuka T, Ichihashi M, Yoshie O: IFN-gamma-inducible expression of thymus and activation-regulated chemokine/CCL17 and macrophage-derived chemokine/CCL22 in epidermal keratinocytes and their roles in atopic dermatitis. Int Immunol 2002, 14:767-773 